\title{
Rus Liberalizminin Gelişimi ve Modern Rusya Siyasetindeki Konumu
}

DOI: 10.26466/opus. 898933

\author{
$*$ \\ Halit Hamzaoğlu* \\ * Dr.Öğr.Üyesi, Kars Kafkas Üniversitesi, İktisadi ve İdari Bilimler Fakültesi, Kars/Türkiye \\ E-Posta: halithamzaoglu85@gmail.com \\ ORCID: $\underline{0000-0001-5249-1911}$
}

\section{Öz}

Çalışmada, Rus liberalizminin Rusya siyasetinde tarihsel ve modern bağlamda oynadı̆̆ etkin rol incelenmiştir. Rus liberalizminin Rus entelektüel, toplumsal ve düşünsel hayatında belirleyici bir konuma sahip olduğu vurgulanmıştır. Çalışmada, Rus liberalizminin, Rusya tarihindeki kriz dönemlerinde ön plana çıktığ ve kurtuluş için muhtelif düzeyli reçete sunduğu gerçekliği temellendirilmiştir. Bu çerçevede özellikle Rus liberalizminin temelde savunduğu ve içselleştirdiği evrim yoluyla değişim tezinin önemi üzerinde durulmuştur. Rus siyasal hayatına yön veren diğer düşünce akımlar gibi, liberalizmin de Rusya'nın özgün yapısının bir ürünü olduğu varsayımı, Rusya'da yaşanan tarihsel ve modern gelişmeler ışı̆̆ında ele alınmıştır. Rusya'nın özgün siyasi, ekonomik, kültürel ve toplumsal yapısının, Rus liberalizminin gelişimine önemli ölçüde etki sağladığı tezi araştırmaya tabi tutulmuştur. Bu özgün yapının, liberalizmin Rusya'da farklı bir boyutta kendini tanımlamasına firsat oluşturduğu belirtilmiştir. Rus liberalizminin, Avrupa liberalizminden farklı olarak, yukarıdan aşağıya teşekkül ettiği hususunun öneminden bahsedilmiştir. Çalışmada Rus liberalizminin toplumun ve devletin şekillenmesinde sahip olduğ u belirleyici konum, tarihsel ve modern çerçevede incelenmiştir.

Anahtar Kelimeler: II. Aleksandr, II. Katerina, Putin, Rus liberalizmi, Rusya siyaseti. 


\title{
Development of Russian Liberalism and Its Position in Modern Russian Politics
}

\begin{abstract}
The purpose of the study was to examine the active role of Russian liberalism in Russian politics in historical and modern contexts. It was emphasized that Russian liberalism had a decisive role in Russian intellectual and social life. It was emphasized in the study that Russian liberalism was in the forefront during crises in Russian history offering a certain "prescription" for salvation at various levels. In this respect, the importance of the thesis of Change Through Evolution, which Russian Liberalism defended and internalized fundamentally, was emphasized. The assumption that liberalism is a product of Russia's original structure just like it is the case in other currents of thought that shaped Russian political life was addressed in the light of historical and modern developments experienced in Russia. The thesis that Russia's specific political, economic, cultural, and social structure had significant effects on the development of Russian Liberalism was subjected to investigation. It was stated that this original structure created an opportunity for liberalism to define itself in a different dimension in Russia. The importance of Russian liberalism, which had a "from-top-to-bottom" structure, unlike European liberalism, was also discussed in the study. The decisive position of Russian Liberalism in the shaping of society and state was investigated in a historical and modern context.
\end{abstract}

Keywords: $\quad$ Alexander II, Catherine II, Putin, Russian Liberalism, Russian Politics. 


\section{Giriş}

Rus liberalizmi, Rusya'daki entelektüel ve toplumsal düşüncenin en önemli eğilimlerinden biridir. Rus liberalizmi, Avrupa liberalizminden farklı olarak, yukarıdan aşağıya teşekkül etmiş ve siyasi düzenin evrimsel dönüşümünü savunmuştur. Bu özellikleri ile Rus liberalizmi, Rusya tarihindeki kriz dönemlerinde ön plana çıkmış ve kurtuluş için muhtelif düzeyli reçete sunmuştur. Rus düşünce ve toplumsal hayatının özgün durumu, Rus liberalizminin tarihsel ve modern gelişim yönünü önemli ölçüde etkilemiştir. Bu bağlamda Rus liberal entelektüeller, devletin evrimsel dönüşümünü savunan bütün siyasi akımlarla bir şekilde düşünsel koalisyona girmişlerdir. Bu bakımdan Rus liberalizmi, bazen ikirciklik ve bazen de çelişki meydana getiren bir simbiyotik modelle gelişim göstermiştir. Söz konusu simbiyotik model, Rus liberalizminin hem tarihsel hem de güncel gelişimine istikamet vermiştir.

Rus liberalizminin tarihsel gelişim süreci ve güncel Rusya siyasetindeki konumunun araştırılması, çalışmamamızın temel konusunu ve sorunsalını oluşturmaktadır. Rusya'nın özgün yapısının, Rus liberalizminin dönüşümünde ve gelişiminde belirleyici rol oynadığı varsayımı çalışmamızın temel istikametine yön vermektedir. Bu varsayım, II. Katerina'dan günümüze Rus liberalizminin ileri sürdüğü entelektüel, toplumsal ve düşünsel girişimler ve söylemler aracilığıyla test edilmektedir. Bu çerçevede çalışmamızda, Rusya'da liberalizmin gelişiminin tarihsel arka planı, II. Aleksandr döneminde gerçekleştirilen liberal içerikli reformlar, Ekim Devrimine giden süreçte Rusya'da liberalizm konuları başlıklar halinde ayrıntılı bir şekilde ele alınmaktadır. Modern Rusya siyasetinde liberalizmin konumu ve işleyiş̧i çalışmamızda üzerinde durulan bir başka önemli husustur. Çalışmada konuyla ilgili özgün kaynaklara yer verilmiştir. Bu bakımdan çalışmanın ilgili literatüre katkı sağlayacağı düşünülmektedir.

\section{Rusya'da Liberalizmin Gelişiminin Tarihsel Arka Planı}

Eşsiz coğrafi, tarihi, sosyo-politik koşullar, Rus liberalizminin özgünlüğünü sağlamış ve gizemli Slav ruhu, özgürlük ideallerine irrasyonel bir boyut kazandırmıştır (Abramov,1997, s.5). Rusya'ya has özgün koşullar 
ve özellikler, bu ülkede klasik liberalizmin kavramsal temellerinin dönüşmesine ve değişmesine yol açmaktaydı (Konovalov, Jurtova ve Kandrokova,2020,s.84). Rus liberalizminin birincil belirgin özelliği, ekonomik veya siyasi teori olarak değil, hukuk felsefesi teorisi olarak ortaya çıkmasındadır. İkincil belirgin özellik ise ekonomik liberalizmin temeli olan laissez faire doktrininin Rus liberalizminin oluşumunda ve gelişiminde önemli bir rol oynamamasıdır (Chijkov,2010, s.76).

Liberalizm, Rusya'ya "aydınlanmış mutlakiyetçilik" kisvesi altında gelmiştir (Novikova ve Sizemskaya,1993,s.126). Bu bağlamda liberalizm "yukarıdan aşağı" uygulanan bir ideolojik çerçeveye sahipti ve temelde Rus İmparatorları sayesinde Rus entelijansiyasının dünya görüşünde kendine yer edinmiş ve kabul görmüştür (Zolotarev ve Zolotareva,2018, s.575). Çeşitli dönemlerde Rus İmparatorları, aristokrasi ve entelijansiya liberal düşüncenin gelişimi için girişimlerde bulunmaktaydılar. Bu çabalar çoğu kez Batı'daki durumun Rus gerçeklerini hesaba katmadan beceriksizce kopyalanmasından zarar görmekteydi. Bu kopyalamalar istenmeyen sonuçlara yol açmış ve liberal değerlerin toplum gözündeki itibarını zedelemiştir.

XVII. Yüzyılda Çar I. Petro'nun sistematik Avrupalılaşma girişimini ve bu bağlamda inşa ettiği "emperyal projeyi" Rusya'da liberal düşüncenin ortaya çıkışının başlangıç noktası olarak ele almak mümkündür (Shneyder,2017, s.64). Mamafih, Rusya'da liberal eğilimli Aydınlanma akımı XVIII. yüzyılın ilk yarısından, yani “II Katerina yönetiminin (17621796) ilk yıllarında", Çar I. Petro dönemine nazaran daha güçlü bir şekilde kendini göstermiş ve esasında bir düşünce sistemi olarak ortaya çıkmıştır (Walicki,2009, s.27). Mamafih, Çariçe'nin liberal eğilimleri Rusya'ya özgü bir nitelik ihtiva etmekteydi. Çariçe, Rusya'da otokrasiye duyulan ihtiyacı karşılamak için, Fransız aydınlarının düşüncelerini benimsemekteydi. Bu bağlamda Montesquieu'nun "geniş topraklara sahip bir ülkeyi yönetmek için monarşinin en uygun yönetim şekli olduğuna" dair savlarını kullanmaktaydı (Moryakov, 2010, s.15). Çariçe'ye göre, otokratik gücün sınırsızlığı, Rusya'nın coğrafi konumundan ve doğasından kaynaklanmaktaydı. (Moryakov, 2010, s.15).

Çariçe'nin bu varsayımları, liberal ve muhafazakârlık arasında seçim yapması gerektiğine işaret etmekteydi. Rusya'ya özgü koşullar ve bu doğrultudaki rasyonel çıkarlar bu seçimi zaruri kılmaktaydı. Çariçe, 
Rusya'ya liberalizmi bir ideoloji olarak aşılamaya çalışmaktaydı; fakat pratikte bir yansıması mevcut değildi. Bunun temel nedeni, liberalizmin otokratik imparatorluk sistemine mesafeli yaklaşmasıydı (Konnikov,2018). Aydınlanma düşüncesinin büyük ölçüde özümseyen II Katerina, Rusya'da önemli siyasi güç olan Rus soylularından (dvoryanlar) destek alabilmek adına, siyasi görüşlerinde kısmi revizyon yapmıştır. Bu çerçevede tahta geçtikten sonra devletçi tutum sergilemeye başlamıştır (Moryakov,2015, s.24). I. Petro'dan itibaren oluşan büyük güç stratejisi ve Rusya'nın hayati çıkarları tezi II. Katerina'yı liberal eğilimden muhafazakâr ilkelere yöneltmiştir. II. Katerina'nın Fransız düşünür Diderto'ya atfen söylediği "siz bir filozof olarak, üzerine yazabileceğiniz her şeyi yüklenebilen kâğıt üzerinde çalışırken; ben zavallı imparatoriçe, kâğıttan çok daha duyarlı olan insan derisi üzerinde çalışıyorum" sözü Çariçe'nin meselelere daha gerçekçi baktı̆̆ının göstergesiydi (Walicki,2009, s.35-36).

Her şeye rağmen, Çariçe II. Katerina liberal ideallerini gerçekleştirmeyi hayal etmekteydi. Bu bağlamda İsviçreli Cumhuriyetçi Lagarpe'yi torunu Aleksandr'a öğretmen olarak atamış ve başlattığı liberal çizginin devam ettirileceğini ummuştur (Konnikov,2018). 1796'da II. Katerina'nın girişimiyle Vsiyakaya Vsyatsina adlı ilk Rus mizah dergisi yayımlanmaya başlamıştır. Bu derginin yayın hayatına başlaması II. Katerina'nın "aydınlanmış liberalizmden vazgeçmek gibi bir düşüncesinin olmadığını" göstermekteydi (Walicki,2004,s.49). Rus liberalizminin önde gelen araştırmacılarından Leontovich'e göre, “II. Katerina'nın tüm hükümdarlık yılları bir anlamda liberal dönem olarak tanımlanabilir" (Leontovich, 1980, s.27). II. Katerina 1766 'da "Rus hukukunu ve yaşantısını rasyonelleştirmek ve modernleştirmek amaciyla" Yasama Komisyonu oluşturdu (Riasanovsky ve Steinberg, 2016, s.268). Komisyon, II. Katerina'nın bizatihi kaleme aldığı "Yönetme Kuralları” (Nakaz) çerçevesinde faaliyetlerini yoğunlaştırmaktaydı. Nakaz, II. Katerina'nın “Rusya'nın yönetimi ve toplumun nasıl organize olması gerektiğine dair vizyonunu" gözler önüne seriyordu (Riasanovsky ve Steinberg, 2016, s.268). Bu vizyon doğrultusunda 1782 'de çıarılan yasaların liberal içeriği ve yansımaları, II. Katerina'nın "tutarlı bir şekilde liberal ilkelere bağlı olduğunun kanıtıdır" (Leontovich, 1980, s.33). Nakaz, "çarpıcı derecede liberal bir belge olup, Fransa'da yasaklanmıştı" (Riasanovsky ve Steinberg, 2016, s.268). 
II. Katerina'nın girişimleri ve desteği ile XVIII. yüzyılda liberaller, Rusya'da etkin bir entelektüel sınıf olarak ortaya çıkmaya başlamıştır. Bu dönemde Rusya' daki sınıfsal mücadele de yükselişe geçmiştir. 1774-1775 yıllarında Pugachov liderliğinde gerçekleşen köylü ayaklanmaları sosyal değişimlere zemin hazırlamış ve yeni burjuva ilişkilerini meydana getirmiştir (Salnikov,2008, s.278). II. Katerina'nın politikalarına karşı “muhafazakâr cephe denilebilecek yeni bir muhalif grup" ortaya çıkmıştır (Vernadsky, 2015, s.215). Çariçe, bu cepheye karşı Rus soylularıyla yakınlaşmıştır. XVIII. yüzyılda Rusya'nın hızla sanayileşmesine ve toplumun feodalizmden kapitalizme geçişine rağmen, burjuva güçlü bir sınıf olarak ortaya çıkmamıştır. Bunun temel nedeni sanayileşmenin önderliğini devletin yapmasındaydı. Rus soyluları da devletle beraber sanayileşme sürecinin gerçekleşmesinde rol almışlardır (Salnikov,2008).

XIX. yüzyılın başlarında Rusya'da liberal düşünceler bir düşünce sistemi olarak alanını genişletmiştir. Bu dönemde Dekabristler ilk kez Rusya'da temel hak ve özgürlükler konusunun anayasal düzlemde ele alınması yönünde liberal talepler ileri sürmeye başlamışlardır. Serfliğin kaldırılması konusu Dekabristler tarafından ilk kez organize bir şekilde dile getirilmekteydi. Çar I. Aleksandr (1801-1825) yönetiminin ilk yıllarındaki liberal tutum, Dekabristleri daha da cesaretlendirmekteydi. Söz konusu taleplere liberal içerik taşısa da Dekabristler' in Rus düşünce tarihindeki yeri tartışmalıdır. Rus düşünürler Herzen ve Ogarev, Dekabristler'i otokrasinin ateşli rakibi olduğunu ve devrimci imajlarını, Rus halk1nın bilincinde pekiştirmişlerdi. Böylelikle, Dekabristler radikal ideolojinin bir parçası olarak tasvir edilmiştir (Vasilyeva,2011, s.67). Vernadsky'e göre, "Dekabristler temelde, Rus politik sisteminin temel eksikliklerinden biri olarak herhangi bir yargı sisteminin bulunmayışına ve buna bağlı olarak muhakeme usullerinin karmaşıklığına" vurgu yapmaktaydılar (Vernadsky,2015, s.264). İvanov'a göre, Dekabristlerin sıralarında hem masonların hem de Slavofiller ve Zapadnikler gibi toplumsal düşünce akımlarının temsilcileri ve imparatorluk otoritesine muhalif olan muhafazakâr aristokratlar yer almaktaydı (İvanov, 2001, s.213). Troçki'ye göre, Dekabristlerin talepleri "soylu entelijansiyanın Çarlığı püskürtmek ve Avrupa'ya açılan pencereyi kırmak adına ilk girişimdi" (Troçki,1927, s.105). Kiyanskaya, Dekabristlerin taleplerini bazı genç Rus soylularının kendilerini eşitleme girişimi olarak ele almaktadır. Bu girişimi "sıradan 
insanları veya serfleri sevdikleri için yapmadıklarına" işaret etmektedir (Kiyanskaya,2017, s.49). Walicki'”ye göre, “dekabrist akım, Rusya'da ilk devrimci örgütlenme olmakla birlikte, aynı zamanda aristokratik muhalefetin bir uzantısı durumundadır" (Walicki,2009, s.105). Dekabristler başlangıçta, Çar I. Aleksandr'ın "aydınlanmış amaçlarına sempati duymuşlardı; fakat pratikte artan muhafazakârlıkla birlikte Çar'a olan inançlarını yitirmişlerdi" (Riasanovsky ve Steinberg, 2016, s.332).

Her halükarda, Dekabristler 1825 'te başarısızlığa mahkûm olduysa da Rus tarihinde entelektüel tartışmaların önünü açmışlardır. Dekabristlerin talepleri liberal, muhafazakâr, devrimci ve radikal ideolojik çözümlemelerin gelişimine muhtelif düzeyde etki sağlamıştır.

Liberalizm gerçek anlamda 1830-1840'lı yıllarda özellikle Rus üniversitelerinde kendine uygun ortam bulmuştur (Solovyev,2014). 1850-1860'11 yıllardan itibaren ise Rus liberalleri sadece üniversiteler aracılı̆̆ıyla değil, aynı zamanda liberal eğilimli dergiler aracılı̆̆ıyla geniş kitlelere ulaşmaya başlamıştır. Bu dönemde Çiçerin, Kavelin ve daha sonraları Gradovsky gibi klasik liberaller sahneye çıkmışlardır (Solovyev,2014). Bu dönemde de Rus liberallerinin doktrini, reform ve özgürlük düşüncesinden beslenmekteydi. Bununla birlikte, liberaller Rusya'nın kalkınması ve düzenin ve sürekliliğin sağlanması bağlamında muhafazakâr düşüncelerle ittifak halindeydiler (Kozlova,2011, s.67). Rus liberalleri Avrupa liberalizmini Rus gerçeklerine uyarlamayı önemsemekteydi; fakat artık Avrupa liberalizminin doğrudan ödünç alınması ve kopyalanması söz konusu değildi (Kozlova,2011). XIX yüzyılda ve XX yüzyılın başlarında Rusya'da yayılan liberal düşüncenin "muhafazakâr fikirlerle başarılı bir şekilde rekabet ettiğini, anayasal monarşiye ve cumhuriyetçi yönetim şekline daha fazla destekçi kazandırdıklarını" söylemek mümkündür (İvannikov,2014, s.24).

Kuşkusuz, hukukçu Boris Nikolayeviç Çiçerin (1828-1904) Rus liberalizminin ve aynı zamanda Rus Batıcılığının öncüleri arasındadır. Çiçerin, Rusya'da var olan derin sorunları, yasal yaşam biçiminin yokluğuna ve bireyin son derece düşük sosyal statüsüne bağlamaktaydı (Chijkov,2010, s.84). Çiçerin, söz konusu sorunların tekâmül (evolyutsiya) yoluyla çözüleceğini ve siyasi radikal eğilimlerin bu tekâmülü engelleyeceğine inanmaktaydı (Chijkov,2010). Çiçerin, bu bağlamdaki liberal muhafazakârlığın "evrimsel gelişim modelini" öncelemekteydi. Çiçerin, liberal muha- 
fazakâr (ohranitelniy liberalizm) görüşleriyle Rus hükümetinin liberal reform programı çerçevesinde birçok zor konuların uhdesinden geleceği ve liberal görüşleri hâkim kılacağı inancını taşımaktaydı (Kokorev, 2003, s.11).

XIX. yüzyıl Rus liberalizminin önemli temsilcileri arasında yer alan teorisyen Konstantin Dmitriyeviç Kavelin (1818-1885) sosyal konularda daha kararlı tekliflere sahipti. Kavelin, siyasi konularda ise daha 1 lımlı ve ihtiyatlı bir çizgideydi (Kochukova,2001, s.31). Kavelin'in liberal görüşleri, Çiçerin liberalizminden farklılaşmaktaydı. Çiçerin'in "saf muhafazakâr liberalizmiyle" Kavelin'in "liberal-halkçı eklektizmi" arasındaki farklar Rusya'nın özgün durumuyla alakalıydı. Bu durum Almanya'daki liberal özgünlüğe oldukça benzemekteydi. (Kochukova,2001). Liberalizm saf haliyle Rus topraklarında gerçek güce sahip olamayacağı için eklektik bir yaklaşımla gelişmekteydi.

Kavelin, reformların yavaş ilerlemesinin toplumsal çelişkilere neden olduğunu sezerek, Rus halkının hoşnutsuzluğunun ortaya çıkma tehlikesini görmekteydi. Kavelin, hukuk bürokrasisinin soyluların tekelinde olmasının Rusya'da devrim için zemin hazırladığını düşünmekteydi (İvannikov, 2014, s.25). Kavelin, devrimin Rusya'da zemin bulmamas1 için bir dizi idari ve sistemsel reform teklifi sundu. Kaveline göre, XIX. yüzyılın başlarında benimsenen Fransız tarzı yönetim anlayışıyla, ülkenin fiilen çar tarafından değil, bakanlar ve üst düzey yetkililer tarafından yönetilmesine yol açmıştır. Bu nedenle, Bakanlar ve üst düzey yetkililer hâkimiyetlerini meşrulaştırmak için bir anayasaya ihtiyaç duymaktayd1lar. Kavelin, bu isteğe karşı çıkmakta ve "Rusya'nın modern gerçeklikleri de hesaba katarak, I. Petro dönemine benzer bir yönetime ihtiyacı olduğuna işaret etmekteydi" (İvannikov, 2014, s.26).

Kavelin, Rusya'da hukuk bilincinin yerleşmesini, liberal zeminin oluşması açısından önemli görmekteydi. Bu bilinci oluşturacak ortam, devlet eliyle gerçekleştirilecek hukuk reformlarına bağlıydı. Kavelin ve diğer eklektik liberaller, "Rusya'da devletin her zaman başlıca örgütleyici olduğunu ve geleceğe yönelik reformların türlerini ve uygulama şekillerini, devletin saptaması gerektiğine" inanmaktaydılar (Walicki,2009, s.239).

Klasik Rus liberalizminin gelişimine katkıda bulunan hukukçu-tarihçi ve Sankt- Petersburg Üniversitesi öğretim üyesi Aleksandr Dmitriyeviç 
Gradovsky'nin (1841-1889) ismi, XIX. yüzyılda Rus akademi çevrelerinde yaygın olarak bilinmekteydi. Gradovsky, Rus ve Avrupa liberalizmini, tarih ve hukuk felsefesi bağlamında sentezleyerek, özgün bir muhafazakâr-liberal düşünce sistemi oluşturmuştur (Gutorov ve Gulyak,2002, s.21). Gradovsky, bütün muhafazakâr liberaller gibi, toplumu devlet yönetimine dâhil etmenin gerekliliğine vurgu yapmaktaydı (Plyashenko,2015, s.123).

Gradovsky, devletin politik bir halkçı (narodnost) biçimi olarak anlaşılmasını ileri sürmekte ve halkın devletin doğal temeli olduğu savını desteklemektedir Devlet, halkçılığın siyasi ve hukuki formasyonundan başka bir şey değildir (Evlampiyev ve Kupriyanov,2016, s.131). Devleti oluşturan ve ahlaki bir kişilik olarak kendini idrak eden bireyler doğa durumunu terk ederek, yaşamlarını ve kültürel yaratıcılıklarını bağımsız olarak sürdürmek için çaba harcarlar (Evlampiyev ve Kupriyanov,2016). Dolayısıyla, insanların ve/veya bireylerin kültürel çeşitliliği bütün dünyanın ve insanlığın iyiliğine katkı sağlamaktadır (Evlampiyev ve Kupriyanov,2016).

Gradovsky, toplumsal güçlerin devlet yönetimine katılımı için yerel yönetimleri fırsat olarak görmekteydi (Plyashenko,2015, s.124). Gradovsky'e göre, dünya uygarlığının ilerleyişi her zaman ulusal (halk) düzeyde gerçekleşmiştir. Elde edilen bütün başarılar halkın kültürel ve tarihsel gelişiminin sonucu olarak belli bir ulusal kökene bağlı olmuştur (Kudryashev,2011, s.46). Bu bağlamda Gradovsky, 1864'de Çar II. Aleksandr (1855-1881) tarafından hayata geçirilen yerel yönetim (zemstvo) reformunu coşkuyla kabul etti. Gradovsky, Zemstvo reformunu köylü reformundan daha fazla önemsemekteydi. Böylelikle, Zemstvo reformunun, köylüleri birey statüsüne yükselttiğini ve özgür kıldığına yürekten inanmaktaydı (Plyashenko,2015).

XIX. yüzyılın ikinci yarısında Rusya'nın dini hayatında da liberal eğilimler kendini göstermeye başlamıştı. Rus Ortodoks Kilisesi ve din adamları arasındaki liberal eğilimler mason localarının üyeleri, dini cemaatler ve resmi düzeyde kiliseden kopmayan mezheplerin yanı sıra Avrupa Hristiyanlığının bazı özelliklerini Rusya'ya aktarmaya çalışan kişileri içermekteydi (Kondakov, 2005, s.16). Çoğu zaman, bu liberaller kendilerini sınırları olmayan ve bütün Hristiyanları birleştiren belirli bir 
"iç kilise formasyonunun" takipçileri olarak görmekteydiler (Kondakov, 2005).

Liberalizmin bütünleşik ideoloji olarak bir sosyal harekete dönüşmesi Rus ılımlı Batııılığının (Zapadnichestvo) teşekkülü ile birebir bağlantılıdır. XIX. Yüzyılın ortalarına doğru Rus siyasal hayatında Zapadnicehstvo düşünce ekolü kendini kuvvetli bir akım olarak göstermeye başlamıştır.

\section{Aleksandr Döneminde (1855-1881) Liberal Reformlar}

II. Aleksandr'ın hükümranlığı döneminde Rus siyasi hayatı, "olayların akışını durdurmaya gücü olmayan liberaller ve ilımlıların ortada durduğu, sağ hükümet ile radikal ve devrimci sol arasındaki çekişmeye sahne olmuştur (Riasanovsky ve Steinberg, 2016, s.394). Çar II. Aleksandr'in "vatansever hassasiyetleri, Kırım Savaşı'nın (1853-1856) akıbetine binaen derin yaralar almıştı. Bu bağlamda reformlar, Rusya için artık kaçınılmaz gözükmekteydi" (Vernadsky, 2015, s.272). Rusya, "yüz elli yıldır başarılı bir devlet ve otokrasinin, kişisel bir biçimi üzerinde oturan büyük bir Avrupa gücüydü. Kırım Savaşı, bu dönemin sona erdiğini gösterdi" (Hosking,2019, s.391).

Kırım Savaşı'ndan sonra, Rusya'da genellikle liberal reformlar olarak adlandırılan bir dizi reform gerçekleşmiştir. II. Aleksandr, aydınlanmayı içselleştiren ve çevrelerinde itibar gören bir grup dürüst ve yetenekli devlet yetkilisiyle (tsinovnikler) beraber hareket etmekteydi (Stolyarov, 2018,s.438). II. Aleksandr öncelikle, Rusya'nın kanayan yarası serflik sorununu çözmeyi amaçlamıştır. II. Aleksandr, serfliğin "aşağıdan çözülmesini beklemektense tepeden inme bir şekilde kaldırılmasını tercih ettiğini" ifade etmiş ve bu çerçevede aristokrasiden destek istemiştir (Riasanovsky ve Steinberg, 2016, s.384). Serfliğin kaldırılması ve diğer önemli reformların hayata geçirilmesi için düzenleyici komisyonlar oluşturuldu. Bu komisyonların hazırladıkları plan, ana komite ve Duma tarafından gözden geçirilmiş ve II. Aleksandr'a sunulmuştur (Vernadsky,2015, s.273). Çar II. Aleksandr serfliğin kaldırılmasını öngören manifestoyu 3 Mart 1861'de imzalamıştır (Vernadsky,2015). Aristokratlar, "serfliğin kaldırılmasına fazla karşı çıkmadılar ve büyük çoğunluğu kaldırılma nedenlerini anladılar" (Hosking,2019, s.396). Uzun vadede ise 
"ekonomik anlamda serflerin özgürlüğ̈̈, toprak sahibi aristokratların için düşüşün başlangıcını" oluşturmaktaydı (Hosking,2019, s.400).

Rusya'nın en köklü sorunu olan serfliğin kaldırılmasının ardından, 1863'de finans reformuna başlanılmıştır. Finans reformu, Rusya'daki para dolaşımını stabilize etmesi beklenen çeşitli önlemleri içermekteydi (Bayura,2012, s.66). Bu bağlamda bütçe reformunun gerçekleştirilmesi de öncelikli bir hedefti. Bu reform, devlet bütçesinin birliğini, rasyonelleşmesini ve kontrolünün güçlendirilmesini sağlayan bir dizi önlemi kapsamaktaydı (Maksimov ve Maksimova,2012, s.135).

1864'teki Zemstvo refomu, “Petro'dan önceki dönemde Moskova Prensliği'nde mevcut olan gerçek anlamdaki ilk yerel yönetim sistemini oluşturmuştu" (Vernadsky,2015, s.275). Her bir kazanın (uyezd) "seçilmiş delegelerine eğitim, kamu sağlığı ve ulaştırma kurumları üzerinde kontrol yetkisinin verilmesi" reformun temel ilkesiydi (Vernadsky,2015). Çar II. Aleksandr döneminde diğer önemli reform ise eğitim alanında gerçekleşmiştir. 1863'de kabul edilen üniversite yönetmeliği ile birlikte, I. Nikolay (1825-1855) dönemindeki uygulamalar ortadan kalkmış ve "üniversitelerin özerkliği garanti altına" alınmıştır (Riasanovsky ve Steinberg, 2016, s.461).

1864 'te başlayan yargı reformu ise Rusya' da siyasi ve hukuk sistemini dönüştürmeye ve anayasal devlet idealine yaklaştırmaya yönelik bir girişimdi (Konovalenkova,2011, s.1). Yargı bağımsızlığının anayasal temellerini oluşturan reform, "yargının yasama ve yürütmeden ayrılmasını, mahkemeler ve hukuk önünde eşitlik ilkesini, sulh ve jüri yargıçlarının seçilmesini, yargıçların ve adli müfettişlerin görevden alınamayacağını" ilan etmekteydi (Dovnar,2010, s.1). Resmi bir delil sistemi yerine, dâhili adli mahkûmiyete dayalı bir değerlendirmesi getirilmiştir (Dovnar,2010). Yeni mahkeme sistemi yerel ve genel olmak üzere, iki parçadan oluşmaktaydı. Yerel mahkemeler, sulh mahkemelerini, sulh hakemleri kongrelerini ve volost adlı kasaba mahkemelerini içermekteydi (Zagarnov,2009, s.238). Yerel mahkemelerin görevleri, küçük hukuk ve ceza davalarını açmak ve ivedilikle ilgilenmekti. Yerel yargıçlar, üç yıllığına seçilmekte ve kararları tek başına vermekteydi. Genel mahkemeler ise bölge mahkemelerinden oluşmaktaydı (Zagarnov,2009). Reformlar, "avukatlara barolar aracılığıyla resmi örgütlenme hakkı tanımaktaydı" (Vernadsky,2015, s.276). 
Liberal karakterli reformlar neticesinde Rusya, ileriye dönük reform deneyimi elde etmiş oldu. Fakat reformlar, içerideki toplumsal çekişmelerin ve radikal temelli fraksiyonların güçlenmesinin engelleyemedi. II. Aleksandr liberal reformlar sayesinde eğitimli Rus toplumundan destek alacağına inanmaktaydı. Zagarnova' a göre, "reformlar tam tersi bir işlev gördü ve halkın yönetime katılım beklentilerini ve umutlarını kışkırttı" (Zagarnov,2009, s.239). Söz konusu beklenti ve umutlar gerçekçi olmad1ğından, hükümet ve muhalifet arasındaki çatışma tırmandı. Sonuç itibariyle, muhalifet radikalleşti ve aktif olarak şiddete başvurmaya başladı (Zagarnov,2009).

Verandsky'e göre, Çar II. Aleksandr liberal sosyal ve idari reformlara rağmen, "şiddetli bir muhalefetle karşılaşmış ve ayrıca devrimci hareketlerin de önünü açmıştır" (Vernadsky,2015, s.284). Riasanovsky ve Steinberg'e göre, "Rusya'daki dönüşüm Avrupa'da gerçekleşmekte olan, romantizmden realizme geçiş olarak tanımlanabilecek değişimin bir parças1 olarak görülebilir" (Riasanovsky ve Steinberg,2016, s.394). Fakat bu dönüşüm Rusya koşullarında "abartılı ve şiddetli bir hal" almıştır (Riasanovsky ve Steinberg,2016). Bu dönemde Rus devrimcileri ve radikalleri arasında devrimci mücadelenin geleceğine yönelik hararetli tartışmalar başladı. (Anisimov,2018, s.337). Henüz reformlar sırasında, ilk devrimci örgüt, Toprak ve Özgürlük (Zemlya $i$ Volya) adıyla kuruldu. 1863'de Rus devrimcileri Polonya'da isyanın çımasına neden olmuşlardır. 1864'te, "Rus reform hareketinin baş aktörlerinden olan Dmitri Çerkassky'nin denetiminde bir toprak reformu başlatıldı" Vernadsky,2015, s.285). Söz konusu toprak reformu önemli bir başarı elde etti ve "Polonya köylülerinin Rus yönetimine bağlı kalmasını" sağladı (Vernadsky,2015). Dolay1sıyla, Rus devrimcileri Polonya isyanından istedikleri sonuçları alamadılar. Polonya isyanı Rus halkındaki "vatansever duyguları yükseltti ve hükümetin durumunu da güçlendirdi" (Vernadsky,2015). Polonya isyanından sonra devrimcilerin ve radikallerin Rus kamuoyundaki etkisi azalmış oldu. 1866'da devrimci Dmitri Karakozov'un II. Aleksandr'a karşı giriştiği suikast girişiminden sonra, liberal basın radikallere karşı kampanyaya başladı (Walicki,2009, s.288).

1870'lerin sonunda, Zemstvo'lar arasında liberal eğilimler artmaya başlamıştır. Bu eğilim Rus liberalizminde "Zemstvo Anayasalcılı̆̆ı" düşüncesinin oluşmasına zemin hazırladı. Bu eğilim temsilcileri II. Alek- 
sandr'dan reformların sürdürülmesini talep etmekteydi. II. Aleksandr'a karşı oluşan Zemstvo Anayasalcılı̆̆l düşüncesi Rus soyluları arasında oluşan liberal gelenek temelinde gelişmekteydi (Panov,2018, s.21). Zemstvo liderleri, haklarının genişletilmesini, faaliyetlerini birleştirecek ve koordine eden umum Rusya merkezi teşkilatının oluşturulmasını savunmaktaydılar. Ekonomik anlamda ise köylüler için yeniden yerleşimin sağlanmasını ve küçük arazi kredilerinin verilmesini talep etmekteydiler (Panov,2018). Liberal eğilimli Zemstvo Anayasalcilı̆̆ı, “özellikle 1906'da ilk Rus Anayasasının hazırlanmasında ve temsili monarşinin oluşturulması sırasında, anayasal sürecin temel istikametini belirlemiştir" (Shutov,2015, s.15).

XIX. yüzyılın ikinci yarısında Rusya' da liberalizm ve milliyetçilik ilişkisi de oldukça belirginleşmişti. Bu dönemde Rusya'da milliyetçi eğilimler heterojen yapıya sahipti. Örneğin, "Mihail Arhangel Birliğii" adlı örgüt daha radikal bakış açısıyla milliyetçiliği yorumluyordu. Ilımlı liberal kanat ise daha farklı bir milliyetçilik anlayışına sahipti (Sokolov,2012, s.130). Rus liberal milliyetçileri demokratik hak ve özgürlüklerin sadece ulus için değil, aynı zamanda Rusya'da milliyetçilik ideolojisinin gelişimi açısından önemli olduğuna vurgu yapmaktaydılar (Sokolov,2012). Greenfeld'e göre, XIX. yüzyılda Rus milliyetçiliği Zapadnichestvo ve Slavofilizm temelli iki ana eksende ilerlemekteydi. Greenfeld, Zapadnichestvo ve Slavofilizm'in "görünüşte iki zıt düşünce olduğunu, aslında ise bir akımın iki yüzü olduğunu" vurgulamaktadır (Greenfeld,2017, s.397). Liberallerin, Zapadnichestvo akımındaki göreli üstünlüğüne rağmen, bu düşünce akımı farklı entelektüel grupları barındırmaktaydı ve gittikçe daha milliyetçi bir çizgiye evirilmekteydi.

II. Katerina döneminden itibaren yeşermeye başlayan liberal milliyetçi anlayış Rusya'nın uluslaşma sürecinin ayrılmaz bir parçası konumundaydı. Uzun süre liberal muhafazakârlık kadar yaygın olmamasının ve devletçi bir perspektifle desteklenmemesinin temel nedeni, Rus İmparatorluğu'nun çok uluslu yapısıydı. III. Aleksandr döneminden (1881-1894) itibaren ise daha önceki y1llarda Zapadnikçi liberallerin ve Slavofillerin başrol oynadığı milliyetçilik akımı, Ruslaştırma politikalarını da beraberinde getirdi.

1881'de suikast sonuncunda öldürülen II. Aleksandr'dan sonra tahta geçen oğlu III. Aleksandr babasından farklı olarak "liberal hareketlere 
karşı kuşku duymaktaydı" (Vernadsky,2015, s.287). Fakat II. Aleksandr'ın reformları sonrası güçlenen kapitalist ekonomi ve siyasal liberalizmin doğal bir sonucu olan milliyetçiliğin de etkisindeydi. II. Aleksandr'dan sonra tahta geçen Romanov hanedanın son temsilcisi II. Nikolay'da (1894-1917) da "ulusun dışında kalan kesimler için acı sonuçları olan, yenilenmiş bir Rus milliyetçiliğini" savunmaktaydı (Riasanovsky ve Steinberg,2016,s.432). Bu bağlamda “Rusya'nın 'medeni' millet olduğu, düzen ve kültürü geri kalmış halklara getirdiği düşüncesi" yaygınlaştırılmaya başlandı (Riasanovsky ve Steinberg,2016, s.433).

\section{Ekim Devrimine Giden Süreçte Liberalizm}

XX. yüzyılın başında Rus liberalizmi adeta "kabuk değiştirdi". Bu dönemde hızla halkın güvenini kazanan sol liberaller ortaya çıtı. Liberalizm entelektüellerin, profesyonel ekonomistlerin, tarihçi ve avukatların uğraş alanı haline geldi. Böylelikle, Rus liberalizmi soylu ve Zemstvo liberalizminden, gerçek anlamda "entelektüel" bir liberalizme dönüştü (Leontiyeva,2012,s.310). Liberalizmin siyasi programı da değişikliğe uğradı. Zemstvo ve yerel konuların yerini, Rusya'daki siyasi sistemin kökten değiştirilmesi meselesi aldı (Leontiyeva,2012).

$\mathrm{Bu}$ dönemde Rus liberalizmine yön veren iki isim ön plana çıkmaktaydı. Pavel Nikolayeviç Milyukov (1859-1843) ve Pyort Struve (18701944), XX. yüzyıl Rus liberalizminin düşünsel dönüşümünde önemli rol oynamışlardır. Milyukov, Kadet Partisi'nin (Anayasal Demokrat Parti) kurucularından ve liberal hareketin tanınmış simasıydı. Milyukov, liberal Osvobozhdenie (Özgürlük) dergisinde aktif rol almaktaydı. Söz konusu dergi, XX. yüzyılın başlarında Rusya'da geniş bir okuyucu kitlesine sahipti (Leontiyeva,2012). Milyukov'un da kurucuları arasında yer ald1ğ1 Kadet Partisi, orta sinıfa hitap etmekteydi. 1905'te kurulan partinin hedef kitlesi "devlet memurları ve şehirlerde yaşayan burjuva kesimiydi" (Vernadsky,2015, s.326). Milyukov kendisini, "yeni liberalizm" diye isimlendirdiği düşüncenin temsilcisi olarak görmekteydi (Leontiyeva,2012, s.311). Milyukov, "Rus liberalizminin klasik Avrupa liberalizminden daha az bireyci, ancak daha demokratik olduğunu" savunmaktaydı (Leontiyeva,2012). Liberalizm XVIII-XXI. yüzyıllarda feodalizme karşı bireysel özgürlükleri savunmanın gerekli olduğunu telkin etmek- 
teydi. Bu o dönemdeki koşullarda oldukça isabetliydi. Milyukov, XIX. yüzyılda Rusya'daki soylu liberalizmin bireysel özgürlüklerle ilgili görüşlerini de bu koşullar çerçevesinde ele almaktaydı. Fakat XX. yüzyılın başlarında değişen koşullarla birlikte, "liberallerin de sosyalistler gibi kitle desteği için savaşması gerektiğini ve bu bağlamda klasik liberalizmin söylemlerinden uzaklaşmasının kaçınılmaz olduğundan" bahsetmekteydi (Leontiyeva,2012).

Milyukov'la birlikte, Kadet'in kurucuları arasında yer alan Pyort Struve, "sosyalistlerin liberalleşmelerini değil, eğer etkili olmak istiyorlarsa liberallerin bir süreliğine sosyal demokratlara dönüşmelerini" önermekteydi (Walicki,2009, s.642). Walicki, Struve'yi Legal Marksist düşüncenin temsilcisi olarak ele almaktadır. Bu bağlamda Legal Marksistler, "kapitalist endüstrileşmenin ve siyasal özgürlüğün gerekliliğini" vurgulamaktaydılar (Walicki,2009, s.640). Legal Marksistler, XIX. yüzyılda kendini gösteren Rus popülizminden farklı olarak, Karl Marks'ın düşüncelerinin mutlak taraftarı değildiler. Bu çerçevede Marks'ın düşüncelerini nesnel ve öznel olarak ayırt etmekteydiler. Struve'nin Marksizm'le ilgili yazılarının fazlalığı Rus Marksizmi'nin Plehanov'la değil, Struve'yle başladığına dair yanlış teorilerin ortaya çıkmasına bile neden olmuştur (Pustarnakov,2018).

Legal Marksizm, Rusya'nın devrime ihtiyaç duymadan, kapitalist yöntemlerle gelişmesinin kaçınılmazlığına vurgu yapmaktaydı. Struve, sosyalist devrimin Rusya açısından erken olduğuna dikkat çekmekteydi. Struve'nin "Marksizmi", "Batı Avrupa burjuva sisteminin ilerici anlamına ve liberal siyasi kurum ve düzene" olan inancı yansitmaktaydı (Kantor,2010, s.20). Bu bağlamda Struve, Rusya' da "anayasal bir monarşinin burjuva-demokratik bir devlete dönüşmesinin tekâmül (evolyutsiya) yoluyla" mümkün olacağına inanmaktaydı. (Kantor,2010). Rusya'da Legal Marksistler, 1900'lı yıllara doğru liberal muhafazakârlığa ve teoloji felsefesine yönelmişler ve böylelikle entelektüel tartışmaların dışında kalmışlardır (Pustarnakov,2018). 1900'de Legal Marksistlerin çoğunluğu, "Rus Sosyal Demokrasi akımıyla bağlarını koparmış" ve ileride liberal Kadet'in çekirdeğini oluşturacak gruplara katılmışlardır (Walicki,2009, s.645).

XX. yüzyılın başlarında Rusya'da ideolojik siyasi örgütlenmelerin ve partilerin sayında artış yaşanmıştır. 1903'te “çoğunluğunu profesörler ve 
özgürlükçü mülk sahiplerinin oluşturduğu 1lımlı liberal gruplar yar1gizli bir yapılanma olan Kurtuluş Birliği'ni kurdular" (Vernadsky,2015, s.326). 1905'te kurulan Kadet, en büyük liberal siyasi örgütlenmeydi. Kadet üyeleri, "İngiliz tarzı anayasal monarşi temelinde ve geniş sosyoekonomik reformların uygulanması yoluyla otokratik rejimin evrimini" savunmaktaydılar (Timohina,2017, s.4). Kadet Partisi'nin liberal ideologları, Rusya'da siyasal düşüncenin gelişimine, siyasi kültürün oluşumuna ve parlamentarizmin ortaya çıkmasında önemli rol oynamışladır (Timohina,2017). Bu dönemde bazı Kadet ideologları, liberallerin ve sosyalistlerin ideallerinin ortak olduğunu onaylamaktaydılar. Söz konusu ideologlar, kendilerini XIX. yüzyıl klasik liberalizminden soyutladılar ve sosyalizmin çeşitli versiyonlarına sempati duymaya başladılar (Yegorov,2009, s.372). Bu nedenle, pek çok Kadet ideoloğu partilerini liberal olarak tanımlamadı ve sosyalizmi bir doktrin olarak olumlu değerlendirdi (Yegorov,2009). Liberallerin öncülük ettiği politik gelişmeler sosyalistleri de derinden etkilemekteydi. Rus sosyalistleri de liberallerin "demokratik hedeflerine ve liberal demokrasinin temel felsefesine katılıyorlardı" (Riasanovsky ve Steinberg,2016, s.419). İki ideoloji arasındaki temel ayrışma Rusya'daki değişimin doğası ile ilgiliydi. Sosyalistler, Rusya'daki değişimin kökten ve radikal bir şekilde hayata geçmesini savunuyorlardı. Liberaller ise tekâmül yoluyla bu değişimin gerçekleşmesini ön plana almaktaydılar.

Siyasi örgütlenmelerin sayısı arttıkça "1904-1905 yılları arasında Rus halkının devrimci düşünceleri birçok farklı şekilde kendini gösterdi (Vernadsky,2015, s.327). Bu dönemde "Zemstvo üyeleri olan liberal toprak sahipleri, reformları tartışmak maksadıyla konferanslar tertip ediyorlardı" (Vernadsky,2015). Bu koşullar 1905'te Rusya'da kitlesel bir devrimin gerçekleşmesine olanak sağladı. Rusya'nın sosyal dönüşümü, “özellikle işçi sınıfının yükselişi, profesyonellerin ve işadamlarının çoğalması, politik muhalefetin büyümesi ile birlikte 1905 Devrimi'ni mümkün kılmıştır." (Riasanovsky ve Steinberg,2016). Hosking'e göre, Rusya'daki "bütün sosyal sınıfların otokrasiye karşı kısa süreli ittifakı, onların geçmişte paylaştıkları yetersizliğin doğal sonucu olarak ortaya çıkmıştı" (Hosking,2019,s.503).

Rus liberalizminin temelde savunduğu ilke olan anayasal monarşi ve parlamentarizm 1905 Rus Devrimi sonucunda gerçekleşti. 30 Ekim 
1905'te Başbakan Kont Witte'nin inisiyatifinde hazırlanan manifestoyla anayasal monarşinin yolu açıldı. Manifestoyla Rus parlamentosu Duma'nın onayı olmadan hiçbir kanun çıkarılmayacaktı (Vernadsky,2015, s.329). Vernadsky'e göre, "liberal muhalefetin başlıca isteklerine yanıt veren bu manifestonun temel amacı devrimci hareketi durdurabilmekti" (Vernadsky,2015). Bu bağlamda sosyalist partiler bu manifestoya karşıydılar ve devrim doktrinlerinin gereği olarak nihai zafer peşindeydiler. Rus sosyalistleri 1905 Devrimi'ni, XVIII. yüzyılda yeşeren ve XIX. yüzyılda ise olgunlaşan Rus liberalizminin taleplerinin ve faaliyetlerinin sonucu olarak ele almadılar. Bu devrimin gerçekleşmesini, proletaryanın ve devrimci hareketin ssrarlı faaliyetlerinin bir sonucu olarak değerlendirdiler.

Ekim manifestosunu takiben, 1906 Temel Kanunu, "imparatoru 'otokrat' olarak tarif etmiş ancak bu terime daha önceki dönemde eşlik eden 'sınırsız' sıfatını dışarıda bırakmıştı' (Hosking,2019, s.512). Bu temel kanunla, Duma'ya hükümetin ve yetkililerin faaliyetlerini gözlemleme hakk1 verilmiştir (Hosking,2019). İlk Duma seçimi 1906'da gerçekleşti. Seçilen “toplam 490 vekilin 190'1 Kadet Partisi'nden, 94 vekil ise 11 lıml köylü gruplarından geliyordu. İvan Petrunkeviç'in önderlik ettiği Kadetler, Duma'da temsil edilen en güçlü parti" konumundaydı (Vernadsky,2015, s.331). II. Nikolay'ın Başbakan Witte'yi görevden alması ve yerine İvan Goremykin'i getirmesi liberallerle Çar'ın arasının açılmasına neden oldu. Bu nedenle 21 Temmuz 1906'da Duma Meclisi feshedildi. II. Nikolay “liberallere imtiyaz vererek, Goremykin'in yerine Pyotr Stolipin'i Başbakanlığa getirdi" (Vernadsky,2015, s.332).

Pyotr Arkadiyeviç Stolipin'in Başbakanlığı dönemi (1906-1911) Rusya tarihinde reform programlarıla ve girişimleriyle birlikte anılmaktadır. Daha önceleri Grodno ve Samara Valiliği (Gubernator) ve İçişleri Bakanl1ğ1 görevlerini icra eden Stolipin, Rus imparatorluk tarihinin önemli bir devlet adamıdı. Stolipin'in, Rusya'yı kargaşa sürükleyen devrimci anarşi durumundan çıarmak ve kalıcı sistematik reform gerçekleştirmek gibi son derece zor siyasi meseleleri çözmesi gerekmekteydi. Stolipin, bu sorunların çözümü açısından özellikle tarım reformunu öncelemekteydi. 1910'da Üçüncü Yasama Meclisi tarafından onaylanan ve 1911'de kabul edilen yasalarla geliştirilen tarım reformu, "köylü komünlerinin dağıtılmasını ve güçlü, bağımsız ve bireysel çiftçilerin ön plana 
çıkmasını sağlayacak şekilde planlanmıştı" (Riasanovsky ve Steinberg,2016, s.430-431). Yeni tarım reformuyla, "her köylü kendi payına düşen toprak parçasının sahibi olma hakkına kavuşmaktaydı ve aynı zamanda köylülerin devlet arazilerini satın almasını finanse edecek tedbirler alınmaktaydı"' (Vernadsky,2015, s.333). Stolipin'in 1911'de Kiev'de tiyatroda suikast sonucu öldürülmesiyle geniş çaplı reformlar tamamlanamamiştır.

Mart 1907'de faaliyete başlayan ikinci Duma'da sosyalistler daha güçlü temsil olunmaktaydılar. 55 sosyalist vekilin Çar II. Nikolay'a düzenlenen suikast girişimiyle bağlantısının ortaya çımasıyla ikinci Duma Haziran 1907'de feshedilmiştir (Vernadsky,2015). Üçüncü Yasama Meclisi (1907-1912) ise ilk iki meclise göre daha uzun süre faaliyet gösterdi. 1912'de açlan dördüncü Yasama Meclisi “Şubat Devrimi'nin olduğu 1917'ye kadar aralıksız hizmet vermiştir" (Riasanovsky ve Steinberg,2016, s.428).

1917'de, XIX. yüzyılda Rus popülistlerin düşü olan "çarlık otokrasisinin yıkılması üzerine doğrudan doğruya sosyalizme geçişi meselesi" Vladimir İliç Lenin tarafından gerçekleştirildi (Walicki,2009, s.656). Böylelikle 1917'de Rus Sosyalist Devrimi'nin gerçekleşmesiyle, Rus liberalizminin temelde savunduğu ve içselleştirdiği tekâmül yoluyla değişim tezi rafa kaldırılmış oldu. Devrim'in mahiyeti ve yöntemi konusunda, iki ana akım ideolojinin çok farklı bakış açılarına sahip olmalarına rağmen, 1917 Devrimi, liberaller ve sosyalistler arasındaki konjonktürel, taktiksel ve geçici düşünsel koalisyonlarının bir sonucuydu. Lenin ise büyük ölçüde bu iki entelektüel düşüncenin tarihsel olarak geliştirdiği elverişli ortamda, radikal çözümlemeler ve hareketler aracılığıyla ve aynı zamanda farklı bir yöntemle nihai hedefine ulaşmıştı. Rusya'nın özgün yapısı, çeşitli ideolojilerin ve düşünce akımlarının koalisyonunu kaçınılmaz kılmaktaydı. Bu eğilim modern Rusya siyasetine de yön vermeye devam etmektedir.

\section{Modern Rusya Siyasetinde Liberalizm}

70 yıl devam eden Sovyet Sosyalist Cumhuriyetler Birliği (SSCB) döneminde Rusya siyaseti, resmi düzeyde önce sosyalist ve daha sonraları ise komünist ideolojinin hegemonyasında kalmıştır. 1987-1988'de Rus top- 
lumu tarafından sosyalizmin bir tür tamamlayıcısı olarak algılanan liberalizm, 90'lara doğru hızla yeniden bağımsız bir ideoloji olarak Rusya siyasetinde yerini almıştır (Sogrin,1997, s.13). Son SSCB lideri Mihail Gorbaçov'un 1980'lerin sonunda başlattı̆̆ perestroyka ve glasnost politikaları köklü değişimleri beraberinde getirdi. Bu dönemde liberal düşüncelerin gelişimi, yeni bir siyasi rejime duyulan ihtiyacı körükledi. Özellikle glasnost politikaları, bu ihtiyacın ortaya çıkmasında özel ve önemli bir rol oynad1 (Pridvorov ve Larina,2010, s.131).

1991'de liberal-demokrasi çatısı altında hareket eden siyasi güçler, aslında Rusya'da barışçıl bir şekilde siyasi iktidarı ele geçirmişlerdir (Sogrin,1997). Yeni oluşan siyasi düzende, liberal-demokrasi çatısı kısa bir süre sonra erozyona uğradı ve liberallerle demokratlar arasında fikir ayrılıkları ortaya çıtı. Bu fikir ayrılıklarını "boşanma" olarak betimleyen Gelman'a göre, ülkenin perestroyka arifesinde ve sırasında geçirdiği süreçler ve 90'ların başlarındaki siyasi atmosfer, liberallerle demokratların ideolojik yörüngelerinde silinmez iz bırakmıştı Gelman,2019, s.5). Gelman, söz konusu fikir ayrılıklarını kuşak çatışması etkenine de bağlamaktadır. Gelman'a göre, “60’11 yılların demokratları, daha genç, daha eğitimli ve daha modern rakiplerine, yani 70'li yılların liberallerine karşı ideolojik mücadelelerini kaybetmişlerdir" (Gelman,2019, s.33). Bu bağlamda 90'lı yılların ilk yarısında liberaller, Rus seçkinleri üzerinde daha fazla etkiye sahipti.

1993'te Duma'ya yapılan seçimlerde liberaller ve demokratlar hezimete uğradı. Rusya ve Batı'da birçok kişi için Vladimir Jirinovski'nin "alaycı bir biçimde" "Liberal Demokrat" olarak isimlendirdiği partisinin başarısı oldukça beklenmedik bir gelişmeydi (Kachanovsky,1995, s.52). 1989 'da kurulan ve milliyetçi tutuma sahip Jirinovski'nin Liberal Demokrat Partisi (Liberalno-Demokraticheskaya Partiya Rossiyi -LDPR) seçimlerde $\% 23$ oy almıştır. Sovyet politik sisteminin mirasçıları olan Komünistler \%13, Tarım Partisi ise \%8 oy almıştır. Sağ liberallerin temsilcisi "Rusya'nın Seçimi" bloğu \%15, kendisini demokratik muhalefet olarak tanımlayan "Yavlinsky bloğu" ise \%7 oy almıştır. Böylelikle, liberaller ve demokratlar 1993 seçiminde göreceli bir yenilgiye uğramışlardır. (Kachanovsky,1995).

Ekonomist Yegor Gaydar’ın liderliğindeki “Rusya'nın Seçimi” bloğu, 90’l1 yıllarda Rusya siyasetinde liberalizminin en önemli temsilcisiydi. 
Gaydar, 1991-1994 yıllarında Rus hükümetinde bir dizi kilit pozisyonda bulunmuştur. Modern Rus ekonomisinin gelişimini belirleyen reformlar onun ismiyle ilişkilendirilmekte ve çoğunlukla "Gaydar Reformları" olarak nitelendirilmektedir (Gerasimov,2009). Bakanlar Kurulu'na bizzat başkanlık eden Rusya Devlet Başkanı Boris Yeltsin, reformların gerçekleştirilmesi sorumluluğunu üstlenmişti. Reformların ekonomik ayağı, Başbakan Yardımcısı Gaydar tarafından belirlenmiş ve uygulanmıştır (Gerasimov,2009).

Gaydar, 1994'te yazdığı ve 1997'de yayınlanan, Devlet ve Evrim (Gosudarstvo ve Evolyutsiya) kitabında, "Rusya'da sosyalizmin sonsuza kadar sona erdiğini, Rusya'nın geleceğinin piyasa ekonomisi ile şekilleneceğini" vurgulamaktaydı (Gaydar,1997, s.11). Gaydar'a göre, "Batı, Rusya açısından ne düşman ne de hayırseverdir. Rusya sorunlarını kendisi çözmelidir ve bu sorunlarla başa çıkılmazsa dünya yüksek Rus medeniyetinin çöküşüne sakince tepki verecektir" (Gaydar,1997, s.167). Gaydar'ın bakışı Rus liberalizminin II. Katerina'dan itibaren geliştirdiği söylemleri ve Rus liberalizminin özgün yapısını gözler önüne sermektedir. Rusya tarihinin en zor döneminde bile, Rus liberalleri Batı'yı taklit etmemeye özen göstermişlerdir.

Gaydar'ın liberal reformları, tükenmiş Rus ekonomisini Batı'nın yardımıyla ayağa kaldırmayı ön plana almaktaydı. 1990'larda reformların ilk sonuçları halk açısından son derece zordu ve yaşam standartları önemli ölçüde düşmüştü. Bu durum Rusya' da hoşnutsuzlukları artırdı. Bütün bunlar, devam eden ekonomik reformlara karşı güçlü bir direnişe yol açtı. Muhalefetin baskısıyla Gaydar hükümeti istifa etmek zorunda kald1. (Gerasimov,2009). Viktor Chernomorydin başkanlığındaki bir sonraki hükumet, reformların hızını yavaşlattı, ancak Rusya'da bir piyasa ekonomisi oluşturmak için önceden kabul edilen stratejiden vazgeçilmedi. (Gerasimov,2009). Gaydar reformlarıyla en acı verici adımlar ve deyim yerindeyse "şok terapi" artık hayata geçirilmişti. Mamafih, radikal liberaller Gaydar reformlarının yeterli olmadığına kanaat getirmişlerdi. Bu bağlamda "kedinin kuyruğunun parçalar halinde değil, derhal ve kökünden kesilmesi gerektiğini" belirtmekteydiler ve piyasa ekonomisine geçişte daha kararlı olunması konusunda 1srarcıydılar (Shevtsova,1999, s.106). İşin ilginç yanı, liberalleşme sonucunda kazananlar grubunda olan oligarklar da reformları eleştirmekteydiler. Bankacı Alek- 
sandr Smolensky, reformları hayata geçirenleri neo-bolşevizmle suçlamiştır (Shevtsova,1999, s.107).

Bu dönemde Rus kamuoyu ve halkı tarafından en fazla eleştirilen mesele özelleştirme (privatizatsiya) konusuydu. Rusya'da iki kuşağın aşına olmadığı özel mülkiyet kavramını yeniden oluşturmak için çok karmaşık bir özelleştirme sürecinin yürütülmesi gerekmekteydi. Aslında, Rusya'daki özelleştirme, düşük fiyatlardan ürün satın alan paravan şirketler aracılığıyla devlet mülkünü yağmalamak suretiyle ortaya çıktı (Kachva,2002, s.11). Bu tür özelleştirmeden elde edilen kar, devlete veya topluma değil, tsinovniklere ve firma sahiplerine yaramış oldu (Kachva,2002, s.11). 1992' den itibaren "devlet girişimleri ortak hisseli şirketlere dönüştü ve vatandaşlara hisse almaları için bonolar verildi, ancak bu hisseler çoğunlukla tsinovnikler ve yöneticiler tarafından alındı" (Riasanovsky ve Steinberg,2016, s.676). Böylelikle, özelleştirmeler sonucunda yöneticiler, küresel pazarlara çıkışı olan gruplar ve tsinovnikler şirketleri ele geçirmiş ve oligarşinin sınırsız gücü ortaya çıkmıştır. Özelleştirme programının başındaki liberal Anatoli Chubays'ın ikna çabalarına karşın, Rus kamuoyu ve halkı özelleştirmenin bir nevi yeni nomenklatura meydana getirdiği ve bürokrasinin bir kısmının istekleri doğrultusunda gerçekleştiği konusunda hemfikirdi (Shevtsova,1999, s.109).

Özelleştirme ve şok terapinin uygulama biçimi, Rus kamuoyunun büyük umutlar beslediği Yeltsin yönetiminin kamuoyu ve aynı zamanda halk nezdindeki desteğini düşürdü. SSCB'nin çöküşü sırasında “Rusya'nın en sevilen politikacısı olan Yeltsin'in 90'lı yılların ortalarına doğru, kamuoyu araştırmalarındaki desteği \%2'ye ve hatta \%1'e kadar geriledi" (Riasanovsky ve Steinberg,2016, s.675). Aslında 12 Aralık 1993'te kabul edilen ve Rusya'yı yeniden Başkanlık yönetimine kavuşturan anayasa referandumundaki zafer Yeltsin'in konumunu güçlendirmişti. Ancak özelleştirme ve geçiş sürecinde yaşanan zorluklar Yeltsin'i zor durumda bırakmıştı. Başından itibaren Yeltsin, dünyaya entegre olmuş ve istikrarını sağlamış bir Rusya hayal etmekteydi. Bu bağlamda SSCB sonrası özgürlükler ve demokrasi konularında birçok başarı sağlanmıştı. Özelleştirmenin ve ekonomik yeniden yapılanmanın kamuoyunda ve halkta oluşturduğu kötümser havayı dikkate alan Yeltsin, "liberalizmden uzaklaşmaya başladı ve bu durum Gaydar gibi bazı liberallerin istifasını beraberinde getirdi" (Riasanovsky ve Steinberg,2016, s.684). 
I. Çeçen Savaşı'nda (1994-1996) Batılı liderler, “Yeltsin'in beklediği gibi davranmadı" ve bu tavır Yeltsin'in dış politikadaki tavrını da önemli ölçüde etkiledi (Shevtsova,1999, s.200). Böylelikle, ekonomik yapılanmanın getirdiği kötümser hava ve I. Çeçen Savaşı Yeltsin'in politikalarında dönüm noktası oldu. 1994-1995 yıllarında Yeltsin, "Rusya'nın en çok ihtiyaç duyduğu şeylerin normalleşme ve istikrar" olduğunu kuvvetli bir biçimde vurguladı (Riasanovsky ve Steinberg,2016, s.684). Mamafih, özelleştirme durmadı ve 1995-1996 yılları arasındaki ikinci özelleştirme aşaması, "Rus hükümetinin bütçe açığını kapatmak için çok daha güçlü hale gelen şirketlerden kredi almasiyla sonuçlandı(Hosking,2019, s.832). Söz konusu oligarşik yapı, “kredilerinin karşıl1ğında devlete satılan şirketlerin hisselerine çok düşük paralar ödeyerek sahip oldu (Hosking,2019). Aynı zamanda oligarklar, Yeltsin'e siyaseten de destek sağladılar ve karşıllğında hükümette üst düzey görevlere getirildiler. Bu oligarklardan biri de Boris Berezovski'ydi (Hosking,2019).

1996'da I. Çeçen Savaşı' nın ve çeşitli ekonomik zorlukların gölgesinde gerçekleştirilen Başkanlık seçimlerinde Yeltsin, Komünist Parti'nin lideri Gennadi Zyuganov'la yarıştı. Seçimlerin ikinci turunda \%53,8 oy alan Yeltsin, yeniden Devlet Başkanı seçildi. Yeltsin'in oligarşinin kontrol ettiği medyadan destek alması ve "komünist rövanş" tehlikesi seçimlerdeki başarısına ve düşen popülaritesinin yeniden yükselmesine zemin hazırlamıştır (Lyutikov,2015, s.94). Liberallerle yaşadığı sorunlara rağmen "komünist rövanş" söylemi "Rusya'nın Seçimi" bloğunun Yeltsin'i desteklemesine olanak sağlamıştır (Lyutikov,2015).

SSCB sonrası Rusya'nın siyasi, ekonomik ve sosyal dönüşümü liberal karakterler taşısa da, aslında bu dönemi geçiş ve reformlar dönemi olarak tanımlamak daha doğru olacaktır. Reformlar, liberal değerlerin toplumda kök salmasından daha çok Rusya'yı yeni koşullara uyum sağlamaya yönelten bir süreçti. Bu geçiş dönemini Rus liberalizmi, muhafazakârlığı ve neo-çarlık arasındaki simbiyotik ilişki modeli olarak tanımlamak mümkündür. Dolayısıyla, XVIII-XIX. yüzyıl Rus düşüncesine has olan simbiyotik ilişki modeli bu dönemde de geçerliliğini korumuştur. Liberalizm, tıpkı Çar I. Petro'dan sonraki dönemde olduğu gibi, SSCB sonrası da oluşan ideolojik boşluğu tek başına dolduramazdı. Rus düşünce yapısı söz konusu simbiyotik ilişki modelini zaruri yapmaktaydı ve bu zaruret entelektüel ve pratik koalisyonların meydana çıkmasına ön 
ayak teşkil etmekteydi. Bu bağlamda post-Sovyet Rusya da bu düşünsel, entelektüel ve pratik eğilimlerden ve koalisyonlardan muaf değildi. Söz konusu düşünsel, entelektüel ve pratik eğilim ve koalisyonlar, Yeltsin sonrası dönemde de geçerliliğini korumaktaydı.

\section{Putin Döneminde Liberalizm}

Yeltsin'in başkanlığının son döneminde çeşitli sağlık sorunlarıyla uğraştı. 31 Aralık 1999'da geleneksel yılbaşı konuşmasında istifa etti ve Rusya Anayasası'na göre Başkanlık seçimine kadarki üç aylık sürede Vladimir Vladimiroviç Putin'in vekâleten Başkanlık görevini üstlenmesi hakkında kararı imzaladığını açıkladı. 26 Mart 2000'de yapılan seçimlerde Zyuganov'la yarışan Putin, oyların \%53,4'nü alarak Rusya Devlet Başkanı seçildi. Bu seçim zaferiyle birlikte Rusya tarihinde yeni bir dönem başlamış oldu.

Putin, iktidarının ilk yıllarında Yeltsin döneminde başlatılan liberal reformları devam ettirdi ve liberal demokratik düzenin geri döndürülemez bir kazanç olduğu düşüncesini benimsedi (Prozorov,2004, s.10). 2000'li yılların başında reformların uygulanması için uygun elverişli ortam vardı. Putin, reformların sürdürülmesi ve Rus ekonomisinin büyümesi bağlamında önemli bir halk desteğine sahipti (Gelman ve Starodubtsev,2014, s.13).

Putin yönetimi, ekonomik liberalleşmeyi önceleyen bir perspektife sahipti. Fakat iç siyasi konularda ve dış politika alanındaki öncelikleri farklıyd. Bu bağlamda yeni yönetimin siyasi çizgisi, devletçi (gosudarstvenniki) ve vatansever (patriyoti) grupların özlemlerine ve söylemlerine daha yakındı (Malinova,2017, s.14). Silovikler (ordu ve istihbarat) ve bu gruba yakın entelektüeller de Putin'e açık bir şekilde sempati duymaktaydılar (Anisimov,2018, s.539). Böylelikle, Putin'in siyasi çizgisi politik anlamda muhafazakâr-paternalist, ekonomik anlamda ise liberal eğilimleri ihtiva eden yeni bir dönemin başlangıcı olmuştur. Putin yönetiminin liberal muhafazakâr söylemleri, XIX. yüzyıldaki Rus liberalizminin devamı niteliğindeydi.

2000'den itibaren Putin yönetiminin temel amaçlarından biri, Yeltsin döneminde siyasi ve ekonomik hayatta etkin güç haline gelen oligarkları dizginlemekti. Bu çerçevede Putin, oligarkların nüfuzunu sınırlamak için 
bir strateji belirledi ve bu stratejiyi Duma aracılığıyla test etme olanağ1 buldu. Duma'da, kendi “Birleşik Rusya" (Edinaya Rossiya) fraksiyonunu oluşturdu ve bu fraksiyon siyasi görevlerde aktif hale gelerek, oligarkların etki alanını zayıflattı (Satarov,2000). Putin'in, 90'larda başlatılan reformları sürdürmesi ve aynı zamanda petrol fiyatlarındaki artıs, Rus ekonomisinin durumunu iyileştirdi ve doğal olarak Rus halkının yaşam standartlarını yükseltti (Anisimov,2018, s.544). Anisimov'a göre, bu eğilim 2000'li yılların sonlarına doğru yerini bir dizi belirsizliğe bıraktı ve Putin döneminde ortaya çıkan yeni oligarşik yapı, kamuoyunda ciddi rahatsızlıklar oluşturdu (Anisimov,2018, s.546). Rusya'nın emtia fiyatlarına güçlü bağımlılığı, özellikle 2008'deki ekonomik kriz sırasında belirginleşti. Petrol fiyatları varil başına yaklaşık 40 dolara düştü ve bu durum Rus devlet bütçesinin tamamen revize edilmesini gerektirmekteydi (Krumm,2010, s.11).

II. Çeçen Savaşı'nda (1999-2009) kazanılan başarı Putin'in kamuoyundaki popülaritesinin yeniden artmasına olanak sağladı. Ancak oluşan ekonomik kriz süreci yeni taktiksel hamleleri beraberinde getirmekteydi. Putin dönemi egemen demokrasi ve muhafazakâr modernleşme kavramlarıyla karakterize edilmekteydi. Kremlin ideologlarından Vladislav Yuryeviç Surkov tarafından 2006'da ileri sürülen egemen demokrasi kavramı, Post-Sovyet Rusya'nın modern ulusal ideolojisidir. Bu ideoloji, Rusya'nın anayasal haklarını ve egemenliğini ön plana alarak, demokratik bir topluma doğru ilerici bir hareket girişimidir (Surkov,2006). Bu bağlamda egemen demokrasi ideolojisi, belirli denetim ve denge sistemine dayanan "normal" bir demokrasinin inşasından önceki bir geçiş dönemini karakterize etmektedir (Grachev,2011, s.109).

2008'de ekonomik kriz ortamında Devlet Başkanı seçilen Dmitri Medvedev'in söz konusu kavramlar yerine, liberal ve demokratik değerlere ve kavramlara üstünlük vermesi beklenmekteydi (Krumm,2010, s.18). Rus kamuoyunda ve ayn zamanda uluslararası toplumda Putin, otoriter sert ve uzlaşmaz politikacı olarak tanımlanırken, Medvedev ılımlı ve liberal olarak tanımlanmaktaydı (Alekseyeva,2012, s.65). Medvedev dönemi liberal entelektüellerin reform beklentilerini artırdı. Pavlovsky'e göre, "Medvedev ilericiydi ve Rusya'nın modernleşmeye gereksinimi olduğunu açıkça söylemekteydi. Fakat Medvedev'in politikaları bir anlamda "Putin 2.0" versiyonundan başka bir şey değildi ve bu bağ- 
lamda Putin'in ilk yıllarındaki tutumuyla benzerlik göstermekteydi" (Pavlovsky,2010, s.3).

Gerçekten de Medvedev, seçim sürecinde liberal reformları destekleyen bir siyasi profil çizmekteydi. Krasnoyarsk Ekonomik Forumu'nda, Medvedev tarafından ilan edilen liberal reform programı, "ekonomide devletin rolünü azaltmayı ve sosyal yaşamda bireysel sorumluklarını artırmayı" hedeflemekteydi (Guriyev,2008, s.34). Liberal çevrelerin, Medvedev'in liberal alternatif olduğuna dair beklentileri bu programla daha da artmıştı. Lysenko'ya göre, "kuşkusuz Medvedev, Kremlin'deki tek liberal ve demokrat figürdü" (Lysenko,2007). Minchenko, Medvedev'i "hem siyasette hem de ekonomide liberal görüşlere sahip kişi” olarak tanımlamaktaydı (Minchenko,2007).

Medvedev'in bahsettiği reformların çoğu kâğıt üzerinde kaldı. Özellikle yeni bir ekonomi oluşturmaya yönelik bazı düşünceleri, 2008'de Gürcistan'la savaş ve küresel mali krizin derinleşmesi sonucunda ertelendi. Bununla birlikte Medvedev yönetimi, Skolkovo'daki teknolojik yenilikler merkezinin açılması, uzun süredir görevde bulunan ulusal Cumhuriyetlerin başkanları, vali ve yöneticilerin değiştirilmesi, yolsuzlukla mücadelede mevzuatın oluşturulması ve iş dünyası üzerinde devlet baskısının azaltılması gibi konularda önemli ilerlemeler sağlamıştır (Ria Novosti,2012).

2012'de Putin'in Kremlin'e geri dönmesiyle birlikte, Rusya'da muhafazakâr ve ulusalcı söylem ve eylemler kendini daha açık bir şekilde ifade etmeye başlamıştır. Rus halkının yeniden canlanan ulusal düşünce etrafında bir araya gelmesi pekiştirilmiştir (Trenin,2015, s.4). 2013'de Putin, muhafazakâr değerlerin savunucusu olarak ortaya çımıştır. Bu sayede Rusya'nın “Batı'dan gelen ahlaki normlara ve 'Orta Çağ'ın kaotik karanlığına” direnebileceği düşünülmekteydi.(Byzov,2014, s.8). 2014'de Kırım'ın ilhak edilmesinin ardından Rus toplumunda ve düşünce hayatında ulusalcı ve muhafazakâr söylemler zirve noktasına ulaşmıştır. Böylelikle, "muhafazakâr dönüşüm" Rus seçkinlerinin resmi ideolojisi haline gelmiştir (Polyakov,2015, s.4).

2019'da Putin, Financial Times'e verdiği mülakatta, liberalizmin "modasının geçtiğini" ve liberallerin "artık herhangi bir şeyi kimseyi dikte etme" noktasında olmadıklarını belirtmiştir (Barber, Foy ve Barker,2019). Kremlin sözcüsü Dmitri Peskov ise Mir televizyonuna verdiği röportaj- 
da, Putin'in “doğası gereği mutlak bir liberal olduğunu ve ekonomik yaklaşımlarda veya sosyal politikalarda liberal bir çizgiye sahip olduğunu" ifade etmiştir (Latuhina,2019).

Putin iktidarının ilk yılından itibaren, komünistler, ulusalcılar ve Avrasyacılar tarafından liberal olarak görülmekteydi. Örneğin, Rus Avrasyacılığı'nın önde gelen temsilcilerinden Alesandr Dugin, Putin'in kendileri açısından "güneş", liberaller açısından ise "ay" olarak görüldügünü vurgulamaktadır (Dugin,2020). Dolayısıyla, Putin döneminde de Rusya siyasi hayatında var olan ikircikli yapı geçerliliğini korumuştur. Putin, kendinden önceki liderler gibi, Rus seçkinlerinin ve kamuoyunun arasinda var olan düşünsel transformasyonu ve/veya koalisyonu verimli bir şekilde kullanmıştır. Rus düşünce ve siyasi hayatında her dönem kendine yer bulan liberalizm, Rus seçkinlerinin ve entelektüellerinin aracıl1ğıyla modern Rusya siyasetinde önemli bir çıkış noktası olmayı sürdürmektedir. Günümüz Rusya'sında Batı tarafından "liberal muhalefet" olarak nitelendirilen Aleksey Navalni ve diğer figürlerin ise liberalizmden çok Slavofil veya diğer düşünce akımlarına daha yakın olduğunu söylemek mümkündür. Tarihsel ve güncel bağlamda Rus liberalizmi, seçkinler ve entelektüeller tarafından kamuoyu ve halka sunulan bir "ilerleme ve denge projeksiyonu" olmaya devam etmektedir.

\section{Sonuç}

Rusya'nın özgün siyasi, ekonomik, kültürel ve sosyal yapısı, Rus liberalizminin gelişimine önemli ölçüde etki sağlamıştır. Bu özgün yapı, liberalizmin Rusya'da farklı bir boyutta kendini tanımlamasına fırsat oluşturmuştur. Liberalizm her ne kadar Avrupa aydınlanmasının bir sonucu olarak ortaya çıkmışsa da, Rusya'da liberalizm odaklı köklü değişimler söz konusu özgünlükten bağımsız olarak gerçekleşmemiştir. Liberalizm, Çariçe II. Katerina'dan günümüze Rus siyasal hayatında önemli bir entelektüel ve pratik düşünce akımı olmaya devam etmektedir.

Rus liberalizmi aynı zamanda farklı düşünce koalisyonları içerisinde gelişim göstermiştir. II. Katerina döneminden itibaren, liberallerle muhafazakârlar arasındaki fiili koalisyon, Rus siyasal hayatına yön vermiştir. Mamafih, Rus liberalizmi XX. yüzyılın başlarında sosyalist düşünce 
akımların yeşermesine de ön ayak teşkil etmiştir. Bu dönemde liberalizmle sosyalizm arasında karşılıklı etkileşim sağlanmıştır.

Hem Yeltsin hem de Putin döneminde Rus liberalizmi liberal teknokratlar aracılığıyla özellikle ekonomik hayatta belirleyici rol oynamışlardır. Rusya'nın özgün yapısı farklı düşünce akımlarının iç içe geçmesini ve etkileşimini zorunlu kılmaktadır. 2014'ten sonra Rus seçkinlerinin muhafazakâr ve ulusalcı vurgularına rağmen, liberalizm Rus siyasal hayatındaki temel konumunu kaybetmemiştir. Bu bağlamda Rus liberalizmi, seçkinler açısından kullanışlı bir entelektüel ve toplumsal düşünce olma vasfını korumaktadır. 


\title{
EXTENDED ABSTRACT
}

\section{Development of Russian Liberalism and Its Position in Modern Russian Politics}

\author{
Halit Hamzaoğlu \\ Kafkas University
}

Russian liberalism is one of the most important trends of intellectual and social thought areas of Russia. Contrary to European liberalism, Russian liberalism appeared in a top-to-down form, and advocated the evolutionary transformation of the political order. With these characteristics, Russian liberalism came to the forefront in crisis periods in the history of Russia, and offered various prescriptions for salvation. The unique condition of Russian thought and social life affected the historical and modern development of Russian liberalism at significant levels. In this respect, Russian liberal intellectuals somehow entered into an intellectual coalition with all political trends, which advocated the evolutionary transformation of the state.

Liberalism came to Russia as disguised in the form of "enlightened despotism". In this context, liberalism had an ideological framework, which was applied in a "top-down" manner, and it took its place and was accepted in the world view of the Russian intelligentsia basically with the Russian Emperors. In Russia, the enlightenment movement that had liberal tendencies showed themselves more strongly in the first half of the $18^{\text {th }}$ Century, in other words, in the "first years of the rule of Catherine II (1762-1796)" than in the period of Tsar Peter I, and emerged as a thought system.

Liberals began to emerge as an active intellectual class in the $19^{\text {th }}$ Century in Russia with the initiatives and support of Katerina II. The class struggle also started to emerge in Russia during this period. Peasant uprisings led by Pugachov in 1774-1775 paved the way for social changes creating new bourgeois relations. Despite the rapid industrialization of Russia in the $18^{\text {th }}$ Century and the transition from feudalism to capitalism in the society, the bourgeoisie did not emerge as a powerful class. The basic reason for this was the leadership of the state in industrializa- 
tion. The Russian nobles also played roles in the realization of the industrialization process along with the state.

At the beginning of the $19^{\text {th }}$ century, liberal thoughts expanded its field as a thought system in Russia. In this period, for the first time in Russia, Decembrists began to put forward liberal demands to deal with fundamental rights and freedoms at the constitutional level. The issue of the abolition of serfdom was first mentioned in an organized manner by the Decembrists. Although the Decembrists were doomed to fail in 1825, they still paved the way for intellectual debates in Russian history. The demands of the Decembrists had varying impact degrees in opposing sides on the development of liberal, conservative, revolutionary, and radical ideological analysis.

In 1830-1840s, liberalism found a suitable setting, especially in Russian universities. As of 1850s towards 1860s, Russian liberals began to contact large masses not only through universities but also through journals that had a liberal tendency. Classical liberals such as Chicherin, Kavelin, and later Gradovsky appeared on the scene during this period. Russian liberals cared about adapting European liberalism into Russian realities; however, there was no longer any direct borrowing and copying of European liberalism. It is possible to argue that liberal thought, which spread in Russia in $19^{\text {th }}$ and early $20^{\text {th }}$ Centuries, "successfully competed with conservative ideas gaining more supporters for the constitutional monarchy and republican government form".

During the reign of Alexander II, Russian political life was the scene of conflicts between the right-wing government and the radical and revolutionary leftists where liberals and moderate people were unable to stop the flow of events. Russia performed a series of reforms, often referred to as liberal reforms after the Crimean War. Alexander II acted with a group of honest and talented state staff (i.e. the tsinovnics) who internalized the enlightenment movement and who were respected in their circles. As a result of the reforms that had a liberal character, Russia gained experience in prospective reforms. However, the reforms could not prevent the strengthening of internal social conflicts and radicalbased fractions. Alexander II believed that liberal reforms would receive support from the educated Russian society. 
Russian liberalism almost "changed its skin" At the beginning of the $20^{\text {th }}$ century in which leftist liberals emerged, and gained the trust of the people quickly. Liberalism became the activity field of intellectuals, professional economists, historians, and lawyers. In this way, Russian liberalism changed from a noble and Zemstvo liberalism to a truly "intellectu$\mathrm{al}^{\prime \prime}$ liberalism. The political program of liberalism also changed. The issue of changing the political system in Russia radically replaced Zemstvo and local issues.

Following the USSR, although the political, economic, and social transformation of Russia had a liberal characteristic, it will be more accurate to define this period as a transition and reform period. The reforms were a process that led Russia to adapt to the new conditions instead of rooting the liberal values within the society. It is possible to define this transition period as a model of the symbiotic relation between Russian liberalism, conservatism, and neo-tsarism.

The hesitant structure, which existed in the Russian political life during the Putin period, has preserved its validity. Like his predecessors, Putin used the intellectual transformation and/or coalition between the Russian elite and public opinion effectively. Liberalism, which has always found a place in Russian thought and political life, continues to be an important initial point in modern Russian politics with the Russian elite and intellectuals.

The unique political, economic, cultural and, social structure of Russia has had important effects on the development of Russian liberalism. In Russia, this unique structure created an opportunity for liberalism to define itself with a different aspect. Although liberalism emerged as a result of the European enlightenment, fundamental liberalism-oriented changes in Russia did not occur independently of the aforementioned originality. Liberalism has continued to be an important intellectual and practical current of thought in Russian political life from Czarina Katerina II to our present time. In this respect, Russian liberalism remains a useful intellectual and social thought for the elite. 


\section{Kaynakça / References}

Abramov, M.(1997). Neokonchennaya Simfoniya Russkogo Liberalizma, ili Vozvrasheniya Belogo Parahoda, Opit Russkogo Liberalizma Antologiya. Moskova: Kanon Yay.

Alekseyeva, A. (2012). Politicheskiye portreti V.V. Putina i D.A.Medvedeva (po materiyale sovremennoy pressi i assotsiativnogo ekspermenta). Politicheskaya lingivistika, 3(41), 64-80.

Anisimov, E. (2018). İstoriya Rossiyi, ot Ryurika do Putina, Sankt Petersburg, Piter Yay.

Barber, L. Foy, H. ve Barker, A. (2019). Vladimir Putin says liberalism has "become obsolete", Financial Times, https://www.ft.com/content/670039ec-98f3-11e9-9573-ee5cbb98ed36 adresinden erişildi. 24.01.2021

Bayura, A. (2012). Finansovaya reforma 1862-1863 gg. Bankayuski Vesnik, 6669.

Byzov, L. (2014). Novoye konservativnoye bolshinstvo kak sotsiyalnopoliticheskiy fenomen. Mir Rosssiyi, 4, 6-34.

Chijkov, S. (2010). Çiçerin i ideologiya ruskogo liberalizma. Orientiri, 6, 7692.

Dovnar, T. (2010) Sudebnaya Reforma 1864. Belarusskaya Yuridicheskaya Entsiklopediya, 3, 603-606.

Dugin, A. (2020). Est nash "solnetsniy" Putin, evraziyskiy, i ih "lunniy" Putin, liberalov, Business gazeta, https://www.businessgazeta.ru/article/493038 adresinden erişildi. 24.01.2021

Evlampiyev, İ. and Kupriyanov,V. (2016). Teleologiya protiv mechanitsizma: dve formi ponimaniya obshestvo i gosudarstva $v$ russkom liberalizma, Jurnal Filosofskiye Nauki, 8, 124-137.

Gaydar, E.(1997). Gosudarstvo i Evoluyutsiya Dni Porajeniya i Pobed. Moskova: Evraziya Yay.

Gelman V. ve Starodubtsev, A. (2014). Vozmojnosti i ogranicheniya avtoritarnoy modernizatsyi: Rossiyskiye reformi 2000-x godov. Evropeyskiy Universitet, Sankt-Petersburg: M-Chentr Yay.

Gelman, V. (2019). "Liberali" versus "demokrati": ideyniye traektoriya postsovetskoy transformatsyii $v$ Rossiyi. Evropeyskiy Universitet, SanktPetersburg: M-Chentr Yay. 
Gerasimov, G. (2009). Gaydar i ego reformi, Ekspert, https://expert.ru/2009/12/17/reformy gaidaral adresinden erişildi. 30.01.2021

Grachev, N. (2011). Suverennaya demokratiya: Sotsiyalno-filosofskiy vzglyad. Vlasty, 2, 106-109.

Greenfeld, L. (2017). Milliyetçilik Moderniteye Giden 5 Yol, İngiltere, Fransa, Rusya, Almanya ve Amerika Örnekleri (A.Yılmaz, Çev.). İstanbul: Alfa Yay.

Guriyev, S. (2008). Neponyatniy Medvedev. Forbes Russia.

Gutorov, V. and Gulyak, İ. (2002). A.D. Gradovskiy -ucheniy i sotsiyalnopoliticheskiy myslitel. Jurnal Sotsiyologiyi $i$ sotsiyalniy antropologiyi, 5(3), 19-57.

Hosking, G. (2019). Rusya ve Ruslar Erken Dönemden 21.Yüzyıla. (K.Acar, Çev.). İstanbul: İletişim Yay.

İvannikov, İ. (2014). Liberalniye teoriyi gosudarstvo i prava v Rossiyi XIX veka. Vestnik Yuridicheskogo Fakulteta Yujnogo Federalnogo Universiteta, 2(2), 24-28.

İvanov, E. (2001). Nauchnaya Kulturnaya Jizn. Pskov, 15, 211-217.

Kachanovsky, İ.(1995). Budushee liberalnoy demokratiyi v Rossiyi. Obshetvenniye Nauki i Sovremennosti, 2, 52-56.

Kachva, L. (2002). Rossiya v 90-e godi. Moskova: Tvoya İstoriya serisi.

Kantor, V. (2010). Petr Struve: Velikaya Rossiya, ili Utopiya, tak ne stavshaya realnostyu. Vestnik Russkoy Xristianskoy Gumanitarnoy Akademiyi, $11(4), 18-42$.

Kiyanskaya, O. (2017). Dekabristi v otechestvennoy istoriyi i istoriografiyi: polemicheskiye zametki. Rossiya $i$ sovremenniy mir, 2(95), 42-56.

Kochukova, O. (2001). K.D. Kavelin kak predstavitel russkogo liberalizma v otechestvennoy i zarubejnoy istoriyografiyi. İstoriyograficheskiy sbornik, 19, 28-40.

Kokorev, A. (2003). B.N. Çiçerin o reformirovaniyi rossiyskogo obshestvo. Vestnik TGU, 4(32), 11-16.

Kondakov, Y. (2005). Liberalnoye i Konservativnoye Napravleniya v Religiyoznih Dvijeniyah v Rossiyi Pervoy Chetverti XIX veka. Sankt-Petersburg: RGPU Yay.

Konnikov, G. (2018). Rossiya i liberalizm-nesovmestimyi dokazano istoriey, Gorod 812 Peterburgskiy Jurnal. https://gorod-812.ru/rossiya-liberalizmnesovmestimyi-dokazano-istoriey/ adresinden erişildi. 30.01.2021 
Konovalenkova, T. (2011). Sudebnaya Reforma 1864 g. kak faktor modernizatsyi sudebnoy sistemi Rossiyskoy Imperiyi. Krasnoyarsk: Sibirskiy Federalniy Universitet Yay.

Konovalov, A. Jurtova, A. and Kandrokova, F. (2020). Kontseptualniye osnovi russkogo i evropeyskogo liberalizma vtoroy poloviny XIX v. v sravnitelnoy perspektive. Tambov Gramota, 13(5), 82-87.

Kozlova, O. (2011). Rossiya i Evropa v diskusiyii rossiyskih liberalov XIX veka. Tambov Gramota, 4(10), 67-71.

Krumm, R. (2010) Faktor Medvedeva, Friedrich Ebert Stiftung, Moskova, 122.

Kudryashev, V. (2011). Rossiyskiye liberali XIX veka o vzaimodeystviyi natsiyonalnogo i obshechelovecheskogo $\mathrm{v}$ istoricheskom progresse. Vestnik Tomskogo Gosudarstvennogo Universiteta, 4(16), 44-49.

Latuhina, K. (2019). Peskov: Putin-gorazdo bolshiy liberal, nejeli nazivniye liberali, Rossiyskaya gazeta. https://rg.ru/2016/12/21/peskov-putingorazdo-bolshij-liberal-nezheli-nazyonye-liberaly.html adresinden erişildi. 30.01.2021

Leontiyeva, O. (2012). Intelektualnaya istoriya Rossiyi XIX-nachala XX. Samara: İzdatelstvo Samarskiy Universitet.

Leontovich, V. (1980). İstoriya Liberalizma v Rossiyi 1762-1914. Paris: YmcaPress.

Lysenko, V. (2007). Putin poluchit vse chto zahocety, politologi o Dmitri Medvedeve, https://www.gazeta.ru/politics/2007/12/10 a 2411943.shtml adresinden erişildi. 30.01.2021

Lyutikov, M. (2015). Vibori Prezidenta RF 1996 goda v memuarnoy literatüre. Izvestiya SPbGETU Leti, 3, 93-99.

Maksimov, Y. ve Maksimova, E. (2012). Printsip edinstva kassi v sisteme upravleniya budjetnyimi sredstvami pri osushestvleniyi finansovoy reformi v Rossiyi 1860-x-1870-x gg. Leningradskiy Yuridicheskiy Jurnal, 1, 135-142.

Malinova, O. (2017). Konstruirovaniye "liberalizma” v postsovetskoy Rossiyi. Politiya, 1(84), 6-28.

Minchenko, E. (2007). Putin poluchit vse chto zahocety, politologi o Dmitri Medvedeve, https://www.gazeta.ru/politics/2007/12/10 a 2411943.shtml adresinden erişildi. 03.02.2021

Moryakov, V. (2010). Ekaterina II-prosvetitel ili konservator? Vestnik Moskovskogo Universiteta, 3, 9-26. 
Novikova, L. ve Sizemskaya, İ. (1993) İdeyniye istoki ruskogo liberalizma. Obshestvenniye Nauki i Sovremennosti, 3, 124-135.

Panov, V. (2018). Zemskiy konstitutsiyonalizm v Rossiyi (vtoroya polovina XIX-nachalo XX vv.). Interaktivnaya Nauka, 4(26), 20-25.

Pavlovsky, G. (2010). Tri yubileya i vlasty-yubilyar. Mirovoy Politicheskiy Forum: Yaroslavl, 1-3.

Plyashenko, T. (2015). Konservativniy liberalizm o poreformennoy Rossiyi: Istoriya odnoy neudachi. Tetradi po konservatizmu, 4, 121-129.

Polyakov, L. (2015). Konservatizm v Rossiyi:Polittechnologicheskiy simulyakr ili istoricheskiy vibor? Russie.Net.Visions, 90, 4-15.

Pridvorov, N. and Larina, E. (2010). Gorbachevskiye reformi i liberalniye pravoviye ideyi. Leningradskiy Yuridicheskiy Jurnal, 1, 130-141.

Prozorov, S. (2004). Russian Conservatism in the Putin Presidency, Danish Institute for International Studies. Working Paper, 20, 2-69.

Pustarnakov,V. (2018). Legalniy Marksizm, Novaya Filosofskaya Entsiklopediya, Elektronnaya Biblioteka. https://iphlib.ru/library/collection/newphilenc/document/HASH44341b139 53d03cc43a844 adresinden erişildi. 03.02.2021

Ria Novosti. (2012). Medvedev: Ot liberalnogo prezidenta k konservativnomu primyeru. https://ria.ru/20120508/644181041.html adresinden erişildi. 24.01.2021

Riasanovsky, N. and Steinberg, M. (2016). Rusya Tarihi (F. Dereli, Çev.), Başlangıçtan Günümüze. İstanbul: İnkilap Yay.

Salnikov, E. (2008). Psevdoliberalizm “prosveshennogo absolyutizma" Ekaterini II i protoliberalniye ideyi russkih prosvetiteley. İzvestiya Rossiyskogo gosudarstvennogo pedagogicheskogo universiteta im A.I. Gertsena, 24(55), 277-282.

Satarov, G. (2000). Chto budet s oligarhami, Kommersant, https://www.kommersant.ru/doc/16652 adresinden erişildi. 24.01.2021

Shevtsova, L. (1999). Rejim Borisa Eltsina. Moskova: Chentr Karnegi Yay.

Shneyder, K. (2017). Liberalizm v Rossii: Istoriya vozniknoveniya otechestvennoy liberalnoy traditsyii. Vestnik Permskogo Universiteta, 3(38), 6471.

Shutov, A. (2015). Zemstvo i konstitutsiyonalizm. Vestnik Moskovskogo Universiteta, Seriya Politicheskiye Nauki, 6, 7-16.

Sogrin, V. (1997). Liberalizm v Rossiyi: peripetiyi i perspektivi. Moskova: Magistr Yay. 
Sokolov, D. (2012). Osebennosti ideologiyi russkih liberalnih natsiyonalistov vtoroy polovini XIX veka. Vestnik Tomskogo Gosudarstvennogo Universiteta, 4(20), 130-132.

Solovyev, K. (2014). Osebennosti liberalizma v Rossiyi, Post Nauka, https://postnauka.ru/faq/33822 adresinden erişildi. 25.01.2021

Stolyarov, N. (2018). Liberalniye reformi Aleksandra II i sovremennosti. Vestnik RUDN Seriya Gosudarstvennoye i Munitsipalnoye Upravleniya, 5(4), 433-443.

Surkov, V. (2006). Natsiyonalizatsiya Budushego, Ekspert, (3), https://expert.ru/expert/2006/43/nacionalizaciya buduschego/ adresinden erişildi. 30.01.2021

Timohina, D. (2017). Sankt-Peterburgskaya Organizatsiya KonstitutsiyonnoDemokraticheskoy Partii v 1905-1917 gg. Sankt-Petersburg: SanktPeterburgskiy Gosudarstvenniy Universitet.

Trenin, D. (2015). Rossiya porvala s odnopolyarnoy sistemoy: pobuditelniye motivi politika Putina. Moskova: Moskovskiy Chentr Karnegi.

Troçki, L. (1927). Nasha Pervaya Revolutsiya, Sochineniya. Moskova-Leningrad: Gosizdat yay.

Vasilyeva, E. (2011). A.İ. Gertsen i N.P. Ogarev o dekabristah, Aktualniye problemi istoricheskiy issledovaniy:vzglyad molodih uchenih, Konferentsiya, 67-73.

Vernadsky, G. (2015). Rusya tarihi. (D.Mizrak ve E.Mizrak, Çev.). İstanbul: Selenge yay.

Walicki,A. (2009). Rus Düşünce Tarihi, Aydınlanmadan Marksizme. İstanbul: İletişim Yay.

Yegorov, A. (2009). Mojno li nazvat Kadetov liberalami? (ob odnoy tendentsiyi sovremennoy istoriografiyi), Diskusiyonniy Klub, http://ecsocman.hse.ru/data/2013/07/04/1251229818/23.pdf adresinden erişildi. 30.01.2021

Zagarnov, A. (2009). Sudebnaya reforma 1864 g. i kapitalisticheskaya modernizatsyii Rossiyskoy İmperiyi. Pratsi gistarichnaga fakultetya BDU, 4, 235-241.

Zolotarev, S. and Zolotareva, T (2018). Vozniknoveniye i razvitiya liberalizma v Rossii. Nauchnie Vedomosty, 45(3), 573-580. 


\section{Kaynakça Bilgisi / Citation Information}

Hamzaoğlu, H. (2021). Rus Liberalizminin gelişimi ve modern Rusya siyasetindeki konumu. OPUS-Uluslararası Toplum Araştırmaları Dergisi, 18(42), 5840-5875. DOI: 10.26466/opus. 898933. 